\title{
Features of the regional identity of the Crimean population
}

\section{Características de la identidad regional de los residentes de la península de Crimea}

\author{
Fisenko Olga* \\ Peoples' Friendship University of Russia (RUDN University), Moscow, Russian \\ Federation \\ ORCID: https://orcid.org/0000-0002-3824-5535 \\ Vakarev Yevgeny \\ Moscow University for the Humanities, Moscow, Russian Federation \\ ORCID: https://orcid.org/0000-0002-8543-7935 \\ Pozina Marina \\ Synergy University, Moscow, Russian Federation \\ ORCID: https://orcid.org/0000-0002-0225-8166

\section{Zhivitsa Olga} \\ Synergy University, Moscow, Russian Federation \\ ORCID: https://orcid.org/0000-0002-2225-1164

\section{Kargina Natalia} \\ Moscow University for the Humanities, Moscow, Russian Federation \\ ORCID: https://orcid.org/0000-0001-8556-3037
}

Received 07-12-20 Revised 07-25-20 Accepted 09-13-20 On line 09-30-20

\section{*Correspondence}

Email: olfiss@list.ru
Cite as:

Fisenko, O., Vakarev, Y., Pozina M., Zhivitsa O. \& Kargina, N. (2020). Features of the regional identity of the Crimean population. Propósitos y Representaciones, 8 (SPE3), e732. Doi: http://dx.doi.org/10.20511/pyr2020.v8nSPE3.732 


\section{Summary}

The article discusses the issues of local identity. The article discusses the issues of local identity. The author proves the influence on the formation of regional identity of the territorial location of the region that organically combines Eastern Christian, Islamic, and Western Christian civilizations. The author proves the influence on the formation of regional identity of the territorial location of the region that organically combines Eastern Christian, Islamic, and Western Christian civilizations.

Keywords: Region; Self-Awareness; Identity; Psychology.

\section{Resumen}

El artículo provee temas relacionados con el estudio de la identidad regional. Se da la justificación teórica de la relevancia del estudio. Se destacan los principales enfoques desarrollados en psicología para el estudio de la identidad. El autor demuestra la influencia en la formación de la identidad regional de la ubicación territorial de la región, donde las civilizaciones cristiana oriental, islámica y cristiana occidental están orgánicamente unidas, así como su historia y lengua.

Palabras clave: Región; Autoconciencia; Identidad; Psicología.

\section{Introduction}

The object of scientific knowledge in modern socio-psychological research is the category of "identity", which for a very long time has been staying off the radar in Russian psychology. It acquired its place in social psychology thanks to the research of P. Burnsa (1986), M.K. Gorshkova (2018), Iu.L. Kachanova, N.A. Shmatko (1994), V.V. Oblivantsova (2016), N. Khazova (2018), V.A. Iadova (2000), and others. The growing interest in the problems of identity is associated with the public's appeal to the issues of regional and interethnic relations within one country. As the analysis shows, there is no generally accepted definition of identity in psychological research. This is that many researchers associate the presence of many types of identity with (social, individual, group, regional, national, etc. identities).

Crimea is one of the most famous sociocultural space on the modern map of Russia. In the contemporary public consciousness of Russians, Crimea is an integral part of the Russian Federation. Historically, Crimea is the largest region that occupies a unique position in the Russian state stratification. The six-year period of Crimea being a part of the Russian Federation showed that the inclusion of new subjects (Crimea and the federal city of Sevastopol) into the Russian Federation is an essential milestone in the formation of regional and territorial identity both in the all-Russian space and on the scale of the Crimean peninsula. At the same time, studies of the Crimean peninsula have socio-psychological, local history, geopolitical, and historical aspects.

\section{The extent of prior research}

The study of regional identity is a promising direction in social psychology. Works by N.V. Antonova (1996), T.S. Baranova (1993), E.M. Zinovieva (1978), N.L. Ivanova (2004), Iu.L. Kachanova, N.A. Shmatko (1998), T.Z. Kozlova (1993), F.R. Maliukova (2003), Iu.G. Ovchinnikova (2003), M.B. Vladimirova (2016), E.E. Pronina (2016), and others covered general issues of personal identity in psychological research.

E.M. Zinovieva carried out a psychological analysis of the peculiarities of the formation of national identity (Zinovieva 1978). 
The study of Russian regional identity was carried out by M.P. Krylov (2003), M.S. Kuropiatnik (2000), L.V. Makarova, G.F. Morozova, N.V. Tarasova (1986), E.Iu. Meleshkina (1999), Iu.L. Kachanov, N.A. Shmatko (1994), and others.

Thus, Russian scientists have repeatedly tried to study regional identity. However, there are relatively few works devoted to the study of the local identity of Crimean residents. In part, the issues of identification of Crimeans were covered in the collection "The Role and Significance of the Reunification of Crimea with Russia" (2015), in the works by L.A. Ozhegova, K.Iu. Sikach, A.Iu. Ozhegova (2018), M.K. Gorshkova (2018), N.V. Ishinova (2016), V.S. Kravchenko (2016), A.A. Kudlai (2016), I.N. Kulinich (2016), V.V. Oblivantsov (2016), V.P. Pavliuk, E.Iu. Savicheva (2016), D.A. Poletaev, B.V. Sokolenko, A.A. Bebka (2016), M.I. Rosenko (2016), and others.

E.V. Kniazeva (2017), V.M. Kapitsyn (2017), Kanakh Ammar Mahmuzh-Almutlak, O.V. Iarmak (2019), and others distinguished "Crimean identity" as a particular type.

\section{Research methods and techniques.}

In our work, we use analytical and descriptive approaches, a data analysis method, and a method of ascent from the abstract to the concrete.

\section{Discussion.}

\section{Psychological approaches to the study of identity}

Leonhard Euler was one of the first to use the concept of "identity" in the mathematical theory of systems. In psychology, this concept was used in 1914 by Z. Freud in the framework of psychoanalysis. In his work "Group Psychology and Ego Analysis", Freud defined it as an emotional-cognitive process of identifying oneself with another subject, group, model (Freud 1990, p. 42). Z. Freud distinguished primary, preoedipal, and secondary identification. Psychological identity consists of hierarchical positive and negative elements. If a person belongs to a minority, then there is a confusion of his own negative identity with the negative models of the minority, which has developed in the dominant group. Accordingly, self-hatred and feelings of inferiority develop. The dominant group seeks to preserve this negative minority identity (Freud 1990, p. 22-23). Identity is identified with the concepts of "self-concept" and "selfawareness". "Self-concept" is a broader concept than "identity". If "self-concept" is an individual's awareness of ideas about himself and their assessment (R. Burns), then "individuality" is the final result. Any individual strives for identification with the group. For an individual, identification means the need for love, support, and protection. The identification process involves the assimilation of norms, values, rules of behavior, mutual expectations of the group.

A new round in the study of identification is associated with the development of social psychology. He made a significant contribution to the theory of identification. V.A. Iadov identified the following types of social identities: a) identification with different communities; b) age-related identification; c) identification according to professional, productionorganizational and material-property criteria; d) civic identity; e) political and ideological value identifications; f) identifications on the basis of behavioral strategies (Iadov 2000, p.8).

Identity as a socio-psychological phenomenon was initially studied in the tradition of the psychoanalytic theory of A. Adler, E. Fromm, E. Erickson, K. Jung, and others.

E. Erickson understands a construct as identity, which is "a firmly assimilated and personally accepted self-perception in all the richness of a person's relationship to the surrounding 
world, a sense of adequacy and stable mastery of the personality of the "I" itself (Erickson 1995). Erikson defines identity as "a sense of self-identity, self-listing, usefulness and belonging to the world" (Erikson 1995, p.82). There is a need to search for the boundaries of identity, differentiation of "aliens" in the structure of individual and collective self-determination. Erickson introduced into psychology the concept of "identity crisis" associated with the complete or partial loss of the system-forming "self" projections. The scientist formulated the concept of negative identity in his work "The concept of identity in interracial interaction".

Further study of the formation of identity is associated with the name of K.G. Jung, connecting a person's identity with the unconscious. Identity is both a static attitude (the determinant of "selfhood") and a dynamic one that determines the interconnection of the previous stages of the "self" formation and real role attitudes. K.G. Jung notes the dual nature of identity associated with the nature of the collective unconscious - "the image of the world, which was formed already in time immemorial and in which certain features, the so-called archetypes, or dominants, crystallized over time" (Jung 2007, p.55). The objects of Jung's scientific knowledge are symbols, heroes, and antiheroes and their role in the self-consciousness of the nation. Thus, scientists have been studying the motives of personality behavior, studying the analysis of the interaction of a person and a group.

Neo-Freudians E. Fromm and T. Adorno (2001) believed that the key need of the individual is interaction with the outside world and the desire to avoid loneliness. Achieving this stable state is possible on the basis of self-identification with values, ideals, and symbols. Late psychoanalysis came to the need to consider personal psychological reactions and states. In the traditions of psychological science 60-80 years. In the XX century, ego identity is presented as a barrier preventing the chaotic mixing of the roles.

T. Leary and R. Wilson developed an information-psychological scheme for the "self" analysis. According to T. Leary, the human psyche consists of eight contours associated with the stages of the "self" evolution. The structure of the contours is based on an informationpsychological construct (bio-survival). Physiological personality traits represent the deepest contour. The emotional-territorial contour determines the spatial self-identification of the "self". The "self" cognitive profile represents a logical-semantic contour. The contours of the highest levels are non-local quantum and meta-programming.

\section{The influence of the geographical position of the Crimean peninsula on regional identity}

The Crimean peninsula occupies a special position in the Russian state stratification. It is washed by the Azov and Black seas. The northern point of the Crimean peninsula is located on the Isthmus of Perekop, which connects it to the continent.

On the modern geopolitical map, the Crimean Peninsula is the largest region of Russia with a number of distinctive features and limited in the Russian sociocultural space, which has a close cultural and economic connection with mainland of Russia. The geographical position of Crimea makes it attractive for many foreign powers, which contributes to the formation of regional identity associated with the idea of a special community of "friends", existing in the world of "aliens".

The special significance of Crimea is confirmed by historical facts. In 1783, by decree of Catherine II, it was annexed to the Russian Empire. Since that period, relations with the Crimean population were of great importance for Russia. Thus, according to the Ukrainian politician Leonid Grach, Crimea has for many years been a symbol of the value of Russian statehood (Grach 1995 p.33). The formation of regional identity during this period of time is influenced by the all- 
Russian values associated with the integrity of the territory, the unity of "ours", and opposition to the "others".

The formation of regional identity was also influenced by the fact that Crimea is a region that combines Eastern Christian, Islamic and Western Christian civilizations. Crimea is a place where West, East and Russia converge.

The presence on the territory of the Black Sea Fleet and the majority of the ethnically Russian population contributed to the fact that even during the period of Ukrainization the territory did not loose touch with the Russian Federation.

Crimea as a multiethnic region is a territory where Russian, Ukrainian and Tatar identities coexist, and political segmentation coincides with ethnic and religious segmentation, which emphasizes the multi-component and multinationality of the peninsula.

Thus, Crimea is a special sociocultural region; the regional identity of its inhabitants is formed in the process of a long history of development on the basis of their own sociocultural code - a system of social, cultural, economic, political and other properties associated with the natural geographic location that ensure internal unity and a certain quality of life.

\section{National self-awareness and regional identity}

Self-awareness is the most important socio-psychological dominant that determines the national and regional identity of the population of Crimea.

The concepts of "nation" and "nationality" do not have clear boundaries (Bromley 1983: p. 50), as they are simultaneously ethnocultural and administrative. the authors of "Essays on the Theory of Ethnos" note that the concept of "nationality" is used to refer to people of the same ethnonym, living both in remote and non-adjacent territories. For example, Ukrainians living in the USSR and Canada retain their ethnic (national) identity from generation to generation. "National" (ethnic) self-awareness - understanding of the state community, religious awareness and emotional attitude to ethnic reality - plays a significant role in determining belonging to an ethnic group. Ethnic identity allows citizens to realize that they belong to a particular ethnic group. Ethnic identity during the collapse of the Soviet Union was replaced by the term "ethnic identity" (Bromley 1983, p. 176-183). Ethnic identity is viewed through the prism of the "we - they" relationship (Iadov 2004). Identity is understood as "self-identification of oneself with a community, an idea of it, the emotional experience of these ideas and a willingness to act" (Vladimirova 2016, p.28). Discussion is the issue of combining ethnic, national-state and regional identity. An analysis of individual constituent entities of the Russian Federation showed that ensuring peace and harmony of various ethnic groups is associated with a state policy of identity. The responsibility for the peaceful coexistence of various ethnic groups in the region is assumed by the state.

The regional identity of Crimea and Sevastopol is linked to the idea of historical unity with Russia. Russianness and the desire to preserve unity with Russia are characteristic of the self-awareness of the inhabitants of Crimea. An active growth of national self-awareness was observed during the Crimean spring 2014. During this period the idea of collectivism, of allRussian unity, stored in the cognitive structures of national self-consciousness, was actualized. "We are together" becomes an integral constant on the basis of which previously lost basic values are recreated. 


\section{Socio-psychological factors contributing to the formation of the Crimean identity}

One of the first concepts of the formation of a national group affiliation was developed by J. Piaget, who, together with A. Weil (1951), analyzed the concepts of "homeland", the images of "other countries" and foreigners. It has been proven that the distinction between "we" and "they" is a necessary condition for the formation of ethnic identity. The formation of ethnic identity is associated with the creation of cognitive models "Homeland". Ethnic feelings are a kind of response to knowledge about ethnic phenomena.

Crimean (regional) identity determines the territorial, political, and historical affiliation of an individual. The concept of regional identity is closely related to the concept of "small homeland" (Krylov 2005) and is defined as "local patriotism". Closely related to this concept is the concept of "ethnos". Following Lev Gumilev, ethnos is understood as "a collective of people that naturally formed on the basis of an original stereotype of behavior, existing as an energy system (structure) opposing itself to all other such collectives, based on a sense of complementarity" (Gumilev 2007, p.858). That is, an ethnos is "a certain group of people (a dynamic system), opposing itself to all other similar collectives ("we" and "not us"), having a special internal structure and an original stereotype of behavior" (Gumilev 1993, p.285). The main features of an ethnos include such psychological characteristics as self-awareness (or identity), a stereotype of behavior (norms of relations between groups, between individuals, groups, etc.). Stereotypes of behavior begin to develop in children in the process of socialization under the influence of a certain cultural environment. Once formed, they are almost impossible to change, even if a person moves to another country and speaks another language. Ethnos is a historically established stable set of people who have stable features of language, culture, psyche, and awareness of their unity and difference from other similar formations. Visions about ethnicity are formed in the process of the development of society. The differentiating features are norms, values, language, ideas about the native land, mythology, folk art, etc. The perception of the members of an ethnic group changes depending on historical conditions.

During the Ukrainian political crisis of 2013-2014, Crimean regional sentiments enhanced. Thus, as the Crimean Republican Organization of the Union of Young Political Scientists of Ukraine stated, $72.2 \%$ of the residents of Simferopol considered themselves patriots of Crimea (Bol' shinstvo krymchan). The strength of regional identity and connection with Russia was confirmed as a result of the referendum on the status of the Republic of Crimea and the city of Sevastopol on March 16, 2014. 96.77\% of the residents of the Republic of Crimea, who took part in the referendum and $95.6 \%$ of the residents of Sevastopol, voted for reunification with Russia. The turnout rate was $83.1 \%$ and $89.5 \%$ (37.38). The lowest turnout was observed in areas where the Tatar population predominated.

Thus, the formation of a regional ("Crimean") identity in Crimea took place under the influence of all-Ukrainian political processes. As a result of the policy pursued by Kyiv, the values of the majority of Crimeans (Russians and other ethnic groups who inhabited Crimea) were the preservation of the Russian language and Russian culture in the conditions of Ukrainization, which took place throughout the entire existence of the independent Ukrainian state. In these conditions, an identity made it possible to preserve its originality, to emphasize the uniqueness of Russian culture and psychological habit.

\section{Language as a means of maintaining identity}

The Crimean peninsula is multinational. The overwhelming majority of the Crimean population is Russian or Russian speaking. According to the 2001 census, $60.2 \%$ of Russians lived in the Autonomous Republic of Crimea and Sevastopol, 23.9\% were Ukrainians, and 10.2\% were Crimean Tatars (The number and composition of the population of Ukraine according to the results). In addition to this ethnic majority, Belarusians, Armenians, Jews, Moldovans, Poles, Greeks, Germans, Bulgarians, Gypsies, etc., lived in Crimea, who, from 1992 to 2013, supported 
Russian symbols to a greater extent than Ukrainian ones. The 2001 census confirms this fact. Thus, $97-98 \%$ of Crimeans use Russian in everyday life, which exceeds the share of Russians. It is the Russian language that influences the formation of group identity, which determines the preferences in the use of the language: "no matter how individually people are different, there is a typically common in their experiences, as" responses "to what is happening before their eyes, in their minds and hearts" (Shpet 1996, p. 341).

Russian identity forms the basis of regional one. Accordingly, the issue of integrating Crimea into Russia was not particularly acute, since even the Ukrainians living in Crimea speak Russian in their everyday life.

The Russian language determines the ethnic identity of the nation. Self-identifying themselves with the Russian ethnos, the inhabitants of Crimea form an idea of themselves and others. The idea of the distance between one's own and someone else's ethnic community contributes to the formation of ethnic stereotypes. A significant role is played by linguistic selfidentification, which determines the use of language and its choice in various communicative situations, language preference. Ethnic identity is closely related to linguistic competence and features of linguistic behavior. "When the base of national self-awareness in terms of the parameters of national culture narrows, the role of historical memory increases" (Vladimirova 2016, p.28). The native language is considered to be the language in which the primary skills of speech interaction are formed. They use an emotional attachment to their native language. The Russian language is becoming a sign of ethnic identity, "common historical destiny". Inclusion in the Russian Federation for residents of Crimea means integration into their ethnic group.

The ethnic-differentiating characteristics are based on the division of the community into "we" and "they". Ethnic identity is expressed through the idea of a territorial community "motherland centrism". In the public mind, language and people are perceived as synonymous. Even the studies of the 70-80s of the XX century described the language as "the fact of greatest importance"; 70-80\% of Estonians, Uzbeks, Georgians, Moldovans considered it the "ethnic identifier" (Ethnosociology 1998, p.153).

During the entire period of Ukrainization, Crimea and Sevastopol were the places where the Russian language dominated in all spheres of life, which gave rise to the linguistic assimilation of Ukrainians, Crimean Tatars, etc. For the majority of the population of Crimea, Russian is the native (mother) language. It forms the primary skills of speech interaction. That is why the Russian language acquires the status of an "nevitable, self-evident realit" (Berger \& Lukman 1996, p. 234).

From the very birth, the inhabitants of Crimea are involved in active language practice. The Russian language plays the role of a symbol of unity with the Russian people. The Ukrainian language was the state language but was little in use. The Crimean Tatar language is of great importance only as a means of communication between its native speakers. Accordingly, the Russian language on the territory of Crimea helps to overcome interethnic barriers.

During the period of Ukrainization, the Russian and Ukrainian languages were taught on the territory of Crimea. The inhabitants knew the literary norm of the two languages, but at the same time retained their ethnic identity. Those Ukrainians who lived in Russia, but belonged to the Ukrainian minority, did not know the literary language of their ethnic group. Among them there was a strong tendency to change their ethnic identity to Russian (Kulinich 2016).

The population of the Crimean peninsula considers their native language as the main means of communication. This fact was used by Ukrainian politicians during political issues. It served as a means of maintaining a regional identity. However, in spite of numerous election promises, the Russian language did not become the second state language. 
Accordingly, a conflict of ethnic identities has been formed. To a greater extent, isolation was characteristic of the Crimean Tatars. According to the Center for Ethnosocial Research, when answering about the status of Crimea, $37 \%$ would like to see it as an independent republic within Russia, $10.5 \%$ - as an independent republic in alliance with Russia, Ukraine and Belarus, $32.1 \%$ - an autonomous republic within Ukraine, $8.3 \%$ - a region of Ukraine. $4.8 \%$ - by the Crimean Tatar autonomy within Ukraine. $4.3 \%$ - an independent Crimean Tatar state, and $0.5 \%$ - as the vilajet within Turkey. Analysis of the data shows that more than $60 \%$ supported the idea of reunification with Russia (Filatov 2012). When answering the question about a social group affiliation, 50.5\% referred them to "Crimeans", "Russians", "Soviet people", "Russians", 24.7\% - to the "citizens of Ukraine", "Ukrainians". That is, state identity is important for Ukrainians and Russians, while ethnic identity is important for Crimean Tatars.

The Russian language "with its emotional potential" (Ross, 1979: 10) and psychological nature has become an ethnic-determinant, a cultural marker, a symbol of unity with the Russian world for most of the inhabitants of the Crimean peninsula. Territory ("motherland"), dwelling ("home"), language ("native speech"), etc. become symbolic markers (Skvortsov, 1995).

Thus, the study showed that the Russian language is a means of maintaining the regional and territorial identity of the Crimean population.

For the residents of Crimea, who consider Russian as their native language, Russian is becoming a symbol of ethnic identity.

\section{Conclusiones}

The conducted research allows us to make the following conclusion:

1) The regional identity of the inhabitants of the Crimean peninsula is a sociopsychological construct formed on the basis of ideas about oneself, about others, about the world and a person in this world. Crimean identity is a characteristic that determines territorial and historical affiliation and is formed on the basis of differentiating the concepts of "we" and "they". The constant "we" semantically means "me and other residents of Crimea, Russia".

2) When living in a certain territory, a person is included in a multi-level system of relationships with society, masters its sociocultural code. As a result, there is a process of identification with other members of society.

3) The formation of the identity of the population of Crimea is influenced by its multinational composition. The period of Ukrainization contributed to the growth of the national consciousness of the Crimeans. At the same time, the national consciousness of the majority of Crimean residents is formed in opposition to the Ukrainian national consciousness. The regional identity of the majority of the population is associated with the idea of historical unity with the mainland of the Russian Federation.

4) The formation of regional identity is based on a system of universal, group and individual values. Regional identity includes Patriotism, personal self-identification, selfidentification with a certain territory, the image of local residents, the memory of history, ancestors, the history of the region, region. Regional identity determines the nature of the behavior of a person in society and distinguishes "friends" and "aliens".

5) Language plays a significant role in the formation of regional identity. It helps people become aware of themselves as part of a socially significant group, a society.

\section{References}

Adorno T. (2001) Study of authoritarian personality. Moscow, Russia, 416

Antonova, N.V. (1996) The problem of personal identity in the interpretation of modern psychoanalysis, interactionism, and cognitive psychology, Questions of psychology. No. 1, $132-142$ 
Baranova, T.S. (1993) Theoretical models of social identification, Social identification of personality. Moscow, Institute of Sociology, Russian Academy of Sciences, 168

Berger, P. L., \& Luckmann, T. (1995) The Social Construction of Reality. A Treatise on sociology of Knowledge. Moscow, Russia, 323

Bromlei, Iu.V. (1983) Essays on the theory of ethnos. Moscow, Russia, 412

Burns, P. (1986) Development of the self-concept and education, Moscow, Russia, 421

Cheboksarov, N.N. (1964) Problems of the origin of ancient and modern peoples. Moscow, Russia, 418

Erikson, E. (1995) Identity: adolescence and crisis. Moscow, Russia, 176

Ethnosociology (1998) Textbook for universities. Yu. V. Harutyunyan. Moscow, Russia, 270

Filatov A.S. (2012) Crimea: ethnocultural guidelines and political attitudes. Issues of the development of Crimea. Edition 16. Simferopol, Russia, pp. 184-190

Freud, Z. (1990) Psychology of the unconscious: Collection of works. Comp., scientific. ed., opening letter author M.G. Iaroshevskii. Moscow, Russia, 448

Fromm E. (1998) Soul of Man. Moscow, Russia, 398

Gorshkov, M.K. (2018) Reunification of Crimea with Russia: socio-historical, political, and sociocultural preconditions, Sociological Science and Social Practice. Vol. 6. No. 2 (22), 7-16

Grach, L. (1995) Geopolitics and modernity. Marxism and modernity. No. 2, 33

Gumilev, L. (2007) Ancient Russia and the Great Steppe. Moscow, Russia, 858

Iadov, V.A. (2000) Social and socio-psychological mechanisms of the formation of social identity. Psychology of self-awareness: Reader. Moscow, Russia, 601

Ishinova, N.V. (2016) The problem of raiding as one of the modern threats to the economic security of the region. Black Sea Scientific and Practical Conference of Moscow State University "Security Problems in the Modern World", May 26-28, 10-12

Ivanova, N.L. (2004) The structure of the social identity of the individual: the problem of analysis. Psychological journal, 2004. Vol. 25, No. 1, 76-96

Jung, K.G. (2007) Archetype and symbol. Moscow, Russia, 55

Kachanov, Iu.L., \& Shmatko, N.A. Semantic space of social identity. Social identity. Moscow, Russia, 1994, part 1, 26-39

Kanakh, Ammar Mahmuzh-Almutlak, \& Iarmak, O.V. (2019) National-state identity of the Crimean students: factors of formation, Interethnic and interregional consent in the student environment of Crimea and Sevastopol: monitoring and analysis of the level of development, 26-34

Kapitsyn, V.M. (2016) "Young Russian" identity: Crimea, 2014-2016. Bulletin of the Perm Scientific Center of URO RAS. No. 5, 11-18

Kapitsyn, V.M. (2017) The referendum in Crimea on March 16, 2014 and the upgrade of Russian identity. Russian political science. No. 1 (2), 14-21

Karnyshev, A.D., \& Karnysheva, O.A., \& Ivanova E.A. (2016) Youth of Asian Russia: Features of Civil and Ethnic Psychology. Monograph. Irkutsk, Russia, 400

Kniazeva, E.V.(2017) The structure of the Crimean identity: the experience of using binary logistic regression to build identification models of Crimeans (based on the research "Open Opinion - Crimea 2016". Telescope: Journal of Sociological and Marketing Research. No. $2,12-16$

Kozlova, T.Z. (1993) Features of social identification at different stages of the life cycle of a person, 321

Kravchenko, V.S. (2016) On the development of financial models for small innovative enterprises for the purpose of economic security of the Black Sea region. Black Sea Scientific and Practical Conference of Moscow State University "Security Problems in the Modern World", May 26-28, 2016, 12-13

Krylov, M. (2005) Regional identity in the historical core of European Russia. Sociological research. Moscow, Russia, No.3, 13 
Krylov, M.P. (2003) Research into Russian regional identity. Culture and mentality of the population of Siberia. Abstracts of the International Scientific and Practical Conference. St. Petersburg, Russia, 48-49

Kudlai, A.A. (2016) Political security in the Crimean Federal District and modern challenges. Black Sea Scientific and Practical Conference of Moscow State University "Security Problems in the Modern World", May 26-28, 2016, 13-15

Kulinich, I.N. (2016) "Aging" of fixed assets in the aspect of the economic security of the region. Black Sea Scientific and Practical Conference of Moscow State University "Security Problems in the Modern World", May 26-28, 2016, 15-17

Kuropiatnik, M.S. (2000) Indigenous peoples and the phenomenon of transnationalization. Collection. Siberia. Problems of Siberian Identity. Ed. Acad. RANS Boronoev A.O. St. Petersburg, Russia, 668

Lebedeva, N.M. (2011) Ethnic and cross-cultural psychology. Moscow, Russia, 424

Liri T. (2001) Seven tongues of God. Moscow, Russia, 224

Makarova, L.V., \& Morozova, G.F., \& Tarasova, N.V. (1986) Regional features of migration processes in the USSR. Moscow, Russia, 256

Maliukova, F.R. (2003) Social identification as a mechanism for the formation of selfconsciousness. Dissertation for the degree of candidate of psychological sciences. St. Petersburg, Russia, 232

Meleshkina, E.Iu. (1999) Regional identity as a component of the problems of the Russian political space. Regional self-awareness as a factor in the formation of political culture in Russia. Moscow, Russia, 344

Nikitina, V., \& Kulakova, V., \& Fisenko, O., \& Girinskaia L. (2017) Control Technology of Social Protection of The Pre-retirement Age Persons in The Russian Federation: The Theoretical Aspect. The Turkish Online Journal of Design Art and Communication, Desember, 1962 - 1969. https: doi://10.7456/1070DSE/183WoS

Oblivantsov, V.V. (2016) Risks and safety of sustainable development of rural areas of the Sevastopol region. Black Sea Scientific and Practical Conference of Moscow State University "Security Problems in the Modern World", May 26-28, 2016, 17-19

Ovchinnikova, Iu.G. (2003) On the ways of resolving the identity crisis. Bulletin of Moscow University. Series 14-Psychology, 96

Ozhegova, L.A., \& Sikach, K.Iu., \& Ozhegov, A.Iu. (2018) Reunification of Crimea with Russia: causes and geopolitical consequences. Geopolitics and ecogeodynamics of regions. Vol. 4 (14). Issue 3, 389-394

Pavliuk V.P., \& Savicheva E.Iu. Directions of increasing investment activity as a condition for the economic security of Russia. Black Sea Scientific and Practical Conference of Moscow State University "Security Problems in the Modern World", May 26-28, 2016, 19-21

Poletaev, D.A., \&Sokolenko, B.V., \& Bebka, A.A. (2016) Sustainable development of the Crimean region in the context of the application of innovative concepts of higher education. Black Sea Scientific and Practical Conference of Moscow State University "Security Problems in the Modern World", May 26-28, 2016, 21-23

Processes of identification of Russian citizens in the social space of "their" and "non-their" groups and communities (1999-2002). Master class of Professor V.A. Poison. Moscow, Russia, 326

Pronina, E.E. (2016) National identity as a security factor. Black Sea Scientific and Practical Conference of Moscow State University "Security Problems in the Modern World", May 26-28, 2016, 155-157

Rosenko, M.I. (2016) Challenges and threats to the security of the Black Sea region in the context of cooperation in the military sphere of Turkey and Ukraine. Black Sea Scientific and Practical Conference of Moscow State University "Security Problems in the Modern World", May 26-28, 2016, 23-26

Ross L., \& Nisbett R. (1999) Man and Situation. Perspectives of social psychology. Moscow, Russia, 190 
Shmatko, N.A., \& Kachanov, Iu.L. (1998) Territorial identity as a subject of sociological research, 245

Shpet, G.G. (1996) Introduction to ethnic psychology. Psychology of social life. Voronezh, Russia, 261-372

The role and significance of the reunification of Crimea with Russia. Round table (March 17, 2015). Ed. by P.A. Merkulov. Oryol, Russia, 192

Vladimirova, M.B. (2016) Latent influence on the mass consciousness of TV audiences as a sign of a threat to their psychological safety. Black Sea Scientific and Practical Conference of Moscow State University "Security Problems in the Modern World”, May 26-28, 2016, 28 29

Zinovieva, E.M. Self-identification in society. Leningrad, Russia, 1978, 232

*The publication has been with the support of the "RUDN University Program 5-100". 